\title{
А.С. Шестопалова
}

\section{ОБРАЗ ОФИЦЕРА В СОЗНАНИИ РОССИЙСКОЙ ОБЩЕСТВЕННОСТИ ПОСЛЕ СВЕРЖЕНИЯ САМОДЕРЖАВИЯ}

\begin{abstract}
Предпринята попытка воссоздать образ представителей офицерского корпуса в сознании российской общественности после свержения самодержавия. На основе изучения отечественной публицистики и воспоминаний современников с помощью дискурс-анализа были выявлены доминирующие концепты при характеристике офицерского корпуса в феврале-октябре 1917 г., а также различные формы репрезентации социальной реальности. Автор приходит к выводу, что закрепление за командным составом российской армии образа контрреволюционера осуществлялось поэтапно.

Ключевые слова: офицерский корпус; общественное сознание; революция 1917 г.; образ; контрреволюция.
\end{abstract}

Революционные события 1917 г. изменили судьбы нескольких поколений. Потрясения, вызванные революцией, подвергли трансформации жизненные устои и традиции различных социальных групп. Особенно отчетливо это сказалось на положении и состоянии офицерского корпуса. Русские офицеры, связанные присягой перед престолом и царем, были поставлены в ситуацию выбора: принять новую власть или бороться за восстановление старого режима.

Несмотря на то что история революции, изучение ее причин, хода, движущих сил и последствий всегда являлись предметом многочисленных исследований, до настоящего времени не прекратились споры о месте и роли в революционных событиях офицерского корпуса. В последнее десятилетие появился ряд работ, в которых была предпринята попытка осмыслить эти проблемы. Особую значимость имеют работы В.Л. Кожевина [1] и И.Н. Гребенкина [2], которые попытались рассмотреть офицерский корпус, изменения его положения в обществе в контексте социально-политических трансформаций, вызванных революцией 1917 г. Реконструкция же образа офицеров в сознании российской общественности, выявление причин его трансформации не являлись предметом специальных исследований. Без осмысления этих сюжетов невозможно в полной мере оценить роль офицерского корпуса в революционных событиях и воссоздать образы революции и ее действующих героев в сознании современников. Так, кем же был офицер российской армии в общественном сознании?

Цель настоящей работы заключается в воссоздании образа офицеров в сознании российской общественности после падения самодержавия. Источниковую базу настоящего исследования составили материалы отечественной публицистики, опубликованные на страницах «Речи», «Разведчика», «Русского инвалида» (с июля 1917 г. - «Армия и флот свободной России»), «Дело народа» накануне и в период революционных потрясений. Особенно важным для реконструкции образа было обращение к воспоминаниям русских военачальников А.И. Деникина, Н.В. Рузского, П.Н. Врангеля,
К.М. Оберучева и их современников. Их воспоминания содержат не только оценки революционных событий, но и восприятия офицеров в общественном сознании. Данное исследование было выполнено в рамках военно-исторической антропологии, что позволило взглянуть на изменения, происходящие в общественном сознании, через призму военного времени [3. С. 17]. Непосредственное значение имело обращение к дискурс-анализу. Под дискурсом мы понимаем особый способ общения и понимания социального мира [4. С. 18]. Использование дискурс-анализа дало возможность выявить доминирующую концепты, используемые при характеристике офицерского корпуса в период революционных потрясений 1917 г., и определить последствия различных репрезентаций социальной реальности для судеб российского офицерства.

Известия о Февральской революции, отречении императора от престола большинство представителей офицерского корпуса получили, находясь на фронтах мировой войны, вдалеке от эпицентра очага революционного движения. По воспоминаниям генерала А.И. Деникина, первое впечатление было ошеломляющим. Но в общем войска отнеслись ко всем событиям совершенно спокойно [5. С. 165]. Офицеры, в своем большинстве, осознавали, что для спасения династии, армии, страны необходимо отречение от престола Николая II. Подтверждением этому служит тот факт, что за все 7,5 месяцев власти Временного правительства не было ни одной серьезной попытки к освобождению царской семьи [Там же. С. 161]. Большая часть офицерского корпуса присягнула на верность новому Временному правительству. Некоторые же из офицеров видели и свою заслугу в свержении самодержавия. В частности, генерал Н.В. Рузский после отречения императора заявлял: «Я убедил его отречься от престола в тот момент, когда для него самого стала ясна неисправимость положения» [6. С. 140].

Вскоре после февральских событий на страницах отечественных периодических изданий была высказана мысль о том, что главным противником революции являлся российский офицер. За представителями офи- 
церского корпуса стал закрепляться образ контрреволюционера. Солдаты в своих командирах увидели главных врагов, которые, по их мнению, препятствовали утверждению их только что приобретенных гражданских прав и свобод. Временное правительство также считало, что у революции нет противников слева, а есть только враги справа. Так как же был сконструирован и закреплен за офицерством образ противника революции и установления демократических свобод? Немалую роль в этом сыграли публицистические работы времен революции, опубликованные на страницах отечественных периодических изданий, и, прежде всего в органах печати социалистических партий, которые пропагандировали идею о том, что главным противником революции являлся офицер российской армии. Обращаясь к анализу публицистических работ, можно проследить динамику изменений общественного мнения и представлений об офицерстве в контексте социально-политических трансформаций. Стоит подчеркнуть, что создание собирательного образа офицера как контрреволюционера не было одномоментным и прошло несколько условных этапов.

На первом этапе, в период с конца февраля до начала апреля 1917 г., начинается процесс формирования и трансляции в массы образа офицера как противника революции. После свержения самодержавия на страницах отечественных периодических изданий выходят в свет заметки и публицистические статьи, содержащие информацию о ходе и главных творцах Февральской революции. В кадетской газете «Речь» от 5 марта была опубликована заметка, где говорилось о том, что против старого порядка «встали все - солдаты, крестьяне, рабочие». Несмотря на то что ряд офицеров приняли активное участие в революционных событиях, а молодые офицеры нередко были замечены в деле революционной пропаганды, их участие и роль замалчивались. По замечанию органа печати кадетов, сначала в Государственную Думу приходили, большей частью, солдаты без своих офицеров. Затем стали приходить целые войска со своими командирами и офицерами [7].

«Правильное информирование» общественности о героях Февральской революции способствовало формированию представлений о безучастности офицеров, об их сочувствии самодержавию. На страницах отечественных периодических изданий активно культивировалось противопоставление «мы» - участники революции и «они», предпочитающие бездействовать. Лозунг «Народ и армия едины», активно транслирующийся на страницах печати, транспарантах, листовках, стал отражением некой новой социальной реальности, которая была порождена Февралем. Однако из этих реалий уже с первых дней начали исключать военачальников российской армии, которые, в большинстве своем, действительно в первые дни революции не приняли участия в ней. Усилился раскол не только между офицерами и гражданскими лицами, явной стала и стена отчуждения между военачальниками и солдатами. «Речь» сообщала, что в зависимости от отношения офи- церов к революционному движению находилось и отношение солдат к своим офицерам [7].

Военный историк А.А. Керсновский в своих публицистических трудах, уже опубликованных в эмиграции, именовал российскую армию перед революцией не иначе как «вооруженным народом». Он неоднократно подчеркивал, что недавние ремесленники, рабочие фабрик, крестьяне видели в офицерах только «господ» [8]. Такое отношение к офицерам солдатской массы укрепляло и нерешительное поведение многих представителей офицерского корпуса в первые дни революции. Один из современников событий на страницах журнала «Разведчик» писал, что «в первые дни революции на улицах были лишь солдаты, рабочие, солдаты, рабочие... часто, очень часто слышались голоса, что нет среди них офицеров» [9. С. 205]. Неготовность, растерянность командного состава в первые дни революции стали одной из первопричин закрепления за представителями офицерского корпуса в общественном сознании образа контрреволюционера.

В рамках первого этапа на процесс закрепления за офицерством образа контрреволюционеров оказал влияние опыт, полученный в Первой русской революции. Участие армии в подавлении революционных выступлений 1905-1907 гг. способствовало конструированию в общественном сознании представлений об офицерах как единственных защитников монархии и борцов с революцией. К этому времени относятся первые трансформации представлений общества об офицерстве, которые были во многом сформированы под влиянием критической кампании, развернувшейся в периодике. Отечественные публицисты подвергли критике традиции, устои, мировосприятие, способ комплектования офицерского корпуса, взаимоотношения офицеров с нижними чинами и миром штатских. При характеристике офицерского корпуса корреспонденты гражданских периодических изданий использовали такие концепты, как «слуги самодержавия», «жрецы милитаризма», «господа», «тупые рутинеры», «члены мертвой касты». Этот сформированный и апробированный негативный образ офицера императорской армии в начале XX столетия вновь будет востребован в первые дни февраля 1917 г.

Главными последствиями репрезентации именно такой социальной реальности, в которой российские офицеры были представлены защитниками монархии, стали оскорбления, обезоруживание, избиения офицеров представителями мира штатских в 1905-1907 гг. [1. C. 56] и жестокие расправы и убийства военачальников солдатами в 1917 г. Уже в первые дни революции появились списки особенно ненавистных офицеров, с которыми солдаты жестоко расправлялись.

В рамках второго периода, который условно можно очертить апрелем-августом 1917 г., были предприняты попытки, прежде всего, со стороны публицистов военных периодических изданий реабилитировать российских офицеров в глазах общественности. В апреле бы- 
ли опубликованы первые заметки «Помогите офицерам», «Идите на встречу», где публицисты настаивали на том, что обвинения в контрреволюционном заговоpe, выдвинутые против военачальников, носили ложный характер и не имели под собой обоснований. Для усиления своей аргументации корреспонденты военных периодических изданий обращались к примерам доблести офицеров на фронтах мировой войны. Несмотря на эти попытки, в обществе бытовали представления, согласно которым офицеры российской армии были противниками революции. Один из корреспондентов журнала «Разведчик» следующим образом описывал эту ситуацию: «Взгляд на офицера эволюционирует весьма мало, по-прежнему приходится слышать заявление о контрреволюционном настроении старшего офицерского состава» [10. С. 487]. Действительно, представления об офицерстве трансформировались медленно, поскольку к этому времени в общественном сознании прочно укрепился ассоциативный ряд: офицер - контреволюционер, «буржуй», «пасынок революции». Уничижительное отношение ко всем, кто в пагонах, была закреплено не только на ассоциативном уровне, но и в повседневной жизни и жизни на фронтах Первой мировой войны. Так, 2 июля был убит солдатами командующий 22-м гренадерским полком подполковник Рыков за то, что уговаривал солдат полка исполнить свой долг. Многие офицеры, уговаривающие солдат исполнить свой долг перед родиной, погибли от своих же пуль при аналогичных условиях [9. С. 205].

Предпринятая попытка реабилитации офицерского корпуса свидетельствовала о появлении новой репрезентации социальной реальности. Исход борьбы двух дискурсов, двух социальных реалий, в центре которых оказался офицерский корпус, оставался не ясным вплоть до начала Гражданской войны.

Продолжавшаяся мировая война привела политическую элиту того времени к осознанию опасности сложившейся ситуации. Военный и морской министр А.Ф. Керенский в подписанном 22 августа 1917 г. приказе «Армии и флоту» заявлял о готовности правительства оказать всемерную поддержку офицерству, которое кровью своею на поле брани доказало верность родине и революции [10. С. 487]. В правительственных кругах заговорили о братском единении солдат и офицеров в дни революции, а все притеснения представителей офицерского корпуса трактовались как незаслуженные, несправедливые, «пережитки старого строя». Изданию приказа А.Ф. Керенского предшествовал доклад военного комиссара юго-западного фронта Гобечиа о необходимости отметить доблесть и заслуги офицерского корпуса в последних боях. Так, и на уровне нового Временного правительства была осуществлена попытка реабилитировать офицерский корпус в сознании общественности. Безусловно, запоздавшие меры, такая политика дискредитации офицерского корпуса оказали влияние на его отношение к революционным событиям 1917 г. и подтолкнули к активным действиям.
Окончательное закрепление за офицерством образа контрреволюционера произошло после Корниловского мятежа в конце августа 1917 г. Генерал-майор К.М. Оберучев в своих воспоминаниях отмечал, что только были намечены пути преодоления трений между солдатами и офицерам, как «вдруг взрыв... мятеж, к которому оказываются прикосновенны высшие воинские чины, генералы офицеры» [11. С. 159]. Офицеры все авансом были взяты под подозрение только потому, что они были офицерами. После выступления Корнилова поднялась страшная волна самосудов над офицерами по подозрению в «корниловщине». Особой трагичностью отличались события в Выборге [12]. Термин «контрреволюционер» стал отождествляться с понятием «корниловец». Употребление таких концептов при характеристике офицерского корпуса не могло не повлиять на отношение к офицерам общественности, опьяненной революцией. После «корниловщины» доверие к офицерам, кое-где еще сохранившееся, было окончательно подорвано [11. С. 160].

Современник событий И.А. Бунин в своей книге «Окаянные дни», содержащей дневниковые записи, упоминал о трагических событиях, произошедших в Экономическом обществе офицеров: «В пять часов вечера узнал, что в Экономическое Общество Офицеров на Воздвиженке пьяные солдаты бросили бомбу. Убито, говорят, не то шестьдесят, не то восемьдесят человек» [13. С. 31]. Автор проиллюстрировал настроение общественности, царившее в дни революции в России. И.А. Бунин в своем произведении описывал спор на площади, очевидцем которого он стал, между прапорщиком и рабочим: «Прапорщик старался говорить как можно мягче, подбирая самые безобидные выражения, стараясь воздействовать логикой. Он почти заискивал, и все-таки рабочий кричал на него: "Молчать, побольше вашему брату надо, вот что!”» [Там же. С. 8]. Этот диалог, зафиксированный в дневнике И.С. Бунина чуть позднее, в феврале 1918 г., с точностью передал ту неприязнь и уничижительное отношение к офицерам, бытовавшие в России практически повсеместно.

Таким образом, в период революционных потрясений 1917 г. в общественном сознании бытовало представление о русском офицере как о главном противнике установления демократических прав и свобод. Под воздействием ряда причин был сформирован ассоциативный ряд: офицер, контрреволюционер, буржуй, слуга самодержавия. Появление негативного образа российского офицера во многом было подготовлено критической кампанией против офицерства, развернувшейся на страницах отечественной периодики до Первой мировой войны. Политические потрясения, вызванные революцией, обострили существующее противостояние между офицерами и нижними чинами, между миром военных и миром штатских. «Правильное» информирование общественности об отношении офицерства к социальнополитическим изменениям в стране, использование идеологических конструктов способствовали расколу не 
только армейского организма, офицерского корпуса, но и всей страны на противоборствующие группы. Фигура российского офицера оказалась в центре борьбы двух противостоящих тенденций в борьбе за общественное мнение: одна была направлена на дискредитацию офицерства, другая пыталась восстановить статус и положение русского офицера. Противоборство двух дискурсов нашло отображение в социальной практике и повсе- дневной жизни в дни революции. Вплоть до начала Гражданской войны оставался открытым вопрос, кто же одержит победу в этой борьбе. Понятно было только одно, что статус и положение российского офицера в обществе уже никогда не будут прежними. Такая политика дискредитации офицерского корпуса в глазах общественности повлияла на отношение офицеров к революционным событиям и на их выбор.

\section{ЛИТЕРАТУРА}

1. Кожевин В.Л. Российское офицерство и Февральский революционный взрыв. Омск, 2011. 260 с.

2. Гребенкин И.Н. Долг и выбор: русский офицер в годы мировой войны и революции. 1914-1918. М. : АИРО-ХХІ, 2015. 528 с.

3. Сенявская Е.С. Психология войн в ХХ веке: исторический опыт России. М.: Российская политическая энциклопедия (РОССПЭН), 1999.383 с.

4. Йоргенсен М.В., Филлипс Л. Дискурс-анализ. Теория и метод. Х. : Гуманитарный центр, 2008. 352 с.

5. Деникин А.И. Очерки русской смуты. Кн. 1, т. 1: Крушение власти и армии (февраль-сентябрь 1917). М. : Айрис-Пресс, 2015. 379 с.

6. Отречение Николая II: Воспоминания очевидцев, документы. Л., 1927. 248 с.

7. Речь. 1917. 5 марта. № 55 (3797).

8. Керсновский А.А. История русской армии. URL: http://militera.lib.ru/h/kersnovsky1/index.html, свободный (дата обращения: 14.04.2016).

9. Гражданин. Идите на встречу // Разведчик. 1917. № 1378. С. 205.

10. Н.В. Доклад об офицерстве // Разведчик. 1917. № 1399-1400. С. 485.

11. Оберучев К.М. В дни революции: Воспоминания участников великой русской революции 1917 года. М. : Кучково поле, 2017.320 с.

12. Дело народа. 1917. 14 сентября. № 154.

13.Бунин И.А. Окаянные дни. М. : ДАРЬ, 2014. 272 с.

Shestopalova Anna S. Tomsk State University (Tomsk, Russia). E-mail: chestopalova94@mail.ru

IMAGE OF AN OFFICER IN THE MINDS OF THE RUSSIAN PUBLIC AFTER THE OVERTHROW OF AUTOCRACY

Keywords: officer corps; public consciousness; revolution of 1917; image; counterrevolution.

The purpose of the article is to reconstruct the image of the officer in the minds of the Russian public after the overthrow of autocracy. Achievement of the set goal includes the following tasks: to establish the reasons of emergence and consolidation of the image of the officer as the opponent of revolution in public consciousness, to identify specificity and dominant concepts at each stage of image formation of the officer of the Russian Army after the fall of monarchy and to define the consequences of establishment the officers as counter-revolutionaries. The methodology of the presented research is based on the achievements of military-historical anthropology. The use of discourse analysis was of direct importance for solving the tasks set in the present work. We consider discourse as a special way of communication and understanding of the social world. The use of discourse-analysis gave an opportunity to reveal the dominant concepts used in the characteristics of the officer corps during the shocks of revolution of 1917, and to determine the consequences of various social reality presentations for the Russian officer's destiny. The source base of the research consists of the materials of the national journalism published during the Revolution of 1917 on the pages of different periodicals such as "Speech", "Scout", "Russian Handicapped", "The Peoples case". Especially important for the reconstruction of the image were the memories of Russian military commanders A.I. Denikin, N.V. Ruzsky, P.N. Vrangel, K.M. Oberuchev and their contemporaries.

In the course of the study, the author came to the conclusion that under the influence of a number of reasons an associative series was formed: officer, anti-revolutionary, bourgeois, servant of autocracy. We have detected that the process of forming and establishing the officer of the Russian army as anti-revolutionary has several conditional stages. The first stage (end of February - early April 1917) the beginning of the formation and transmission of the image of the officer as an opponent of the revolution. The second stage (AprilAugust 1917) - an attempt to rehabilitate the officer corps in the public eye. The third stage began with the suppression of the Kornilov Rebellion and marked the strong fixation of the image of the officers as anti-revolutionary.

The author substantiates the idea that the figure of the Russian officer was in the center of the struggle of two opposing discourses, two representations of the social reality, one of which represented the officer as an opponent of the revolution and the establishment of democratic rights and freedoms, and another one, as a defender of the new political system in the fatherland. The confrontation between the two discourses was reflected in social practice and everyday life of Russian society during the revolution.

\section{REFERENCES}

1. Kozhevin, V.L. (2011) Rossiyskoe ofitserstvo i Fevral'skiy revolyutsionnyy vzryv [Russian officers and the February revolutionary explosion]. Omsk: Omsk State University.

2. Grebenkin, I.N. (2015) Dolg i vybor: russkiy ofitser v gody mirovoy voyny i revolyutsii. 1914-1918 [Duty and choice: Russian officer in the years of world war and revolution. 1914-1918]. Moscow: AIRO-XXI.

3. Senyavskaya, E.S. (1999) Psikhologiya voyn $v$ XX veke: istoricheskiy opyt Rossii [. Psychology of wars in the 20th century: Russian historical experience]. Moscow: ROSSPEN.

4. Jorgensen, M.V. \& Phillips, L. (2008) Diskurs-analiz. Teoriya i metod [Discourse analysis. Theory and method]. Translated from English by A.A. Kiseleva. Kharkov: Gumanitarnyy tsentr.

5. Denikin, A.I. (2015) Ocherki russkoy smuty [Essays on the Russian Troubles]. Vol. 1(1). Moscow: Ayris-press.

6. Shchegolev, P.E. (1927) Otrechenie Nikolaya II: Vospominaniya ochevidtsev, dokumenty [Renunciation of Nicholas II: Memoirs of eyewitnesses, documents]. Leningrad: Kransaya gazeta.

7. Rech'. (1917). 5th March.

8. Kersnovskiy, A.A. (n.d.) Istoriya russkoy armii [History of the Russian army]. [Online] Available from: http://militera.lib.ru/h/kersnovskyl/index.html. (Accessed: 14th April 2016)

9. Anon. (1917) Grazhdanin. Idite na vstrechu [Citizen. Go towards us]. Razvedchik. 1378. pp. 205.

10. N.V. (1917) Doklad ob ofitserstve [Report on the officers]. Razvedchik. 1399-1400. pp. 485.

11. Oberuchev, K.M. (2017) V dni revolyutsii: Vospominaniya uchastnikov velikoy russkoy revolyutsii 1917 goda [. In the days of the revolution: Memoirs of participants in the Great Russian revolution of 1917]. Moscow: Kuchkovo pole.

12. Delo naroda. (1917) 14th September.

13. Bunin, I.A. (2014) Okayannye dni [Cursed days]. Moscow: DAR. 